\title{
Bad banks choking good banks: simulating balance sheet contagion
}

\author{
Saed Khalil \\ Palestine Monetary Authority, Palestine \\ Stephen Kinsella \\ University of Limerick, Republic of Ireland
}

We investigate the propagation of contagion through banks' balance sheets in a two-country model. We simulate an increase in non-performing loans in one bank, and study the effects on other banks and the macro-economy of each country. We show that credit crunches destabilize each economy in the short run and in the long run reduce potential output. We quantify this loss.

Keywords: credit crunch, contagion, stock-flow consistent models

JEL codes: E32, E37, E51, G33

\section{INTRODUCTION}

The recent crisis has highlighted the role systemic liquidity plays in spreading funding contagion through the web of interlinked banks and other financial institutions. There is a need for models that can identify counterparty risk exposures, shock transmission processes, and other 'fault lines' at the systemic level.

To understand the role liquidity plays within interconnected sets of balance sheets, this paper studies the evolution of an increase in non-performing loans in one bank within a two-country, five-sector model. Financial fragility, defined as the vulnerability of a financial system to a financial crisis, can affect both the short-term and long-term evolution of the economy (Anand et al. 2013). Empirically our model is closest to Anand et al.'s (2013), where a change in the size of a credit crunch around a critical value determines whether the network of banks collapses or not.

We define a credit crunch event as a sudden shortage of funds for lending within private banks that result in a decline in lending by those banks. Credit crunches can occur in banks when there is an unexpected decline in the value of their collateral (for example in the case of Ireland's banks (Kinsella/Lyons 2011)). Credit crunches can occur when reserve or other macro-prudential regulatory requirements change, or when governments impose direct credit controls (as in the case of Malaysia in 1998). Credit crunches can, of course, come from an increase in the risk of system-wide insolvency, as witnessed in Ireland, Greece, and Portugal and Cyprus since 2007 (Kinsella 2012).

Figure 1 shows a credit crunch at work. We see the increase in non-performing loans as a percentage of total loans in the United States from 2005 to 2009 on the left axis. We see the increase of non-performing loans over this period, from less than 1 percent of total loans in 2005 to 5.0 percent in 2009 . On the right-hand axis we see the increase in

Received 28 February 2014, accepted 1 December 2014 


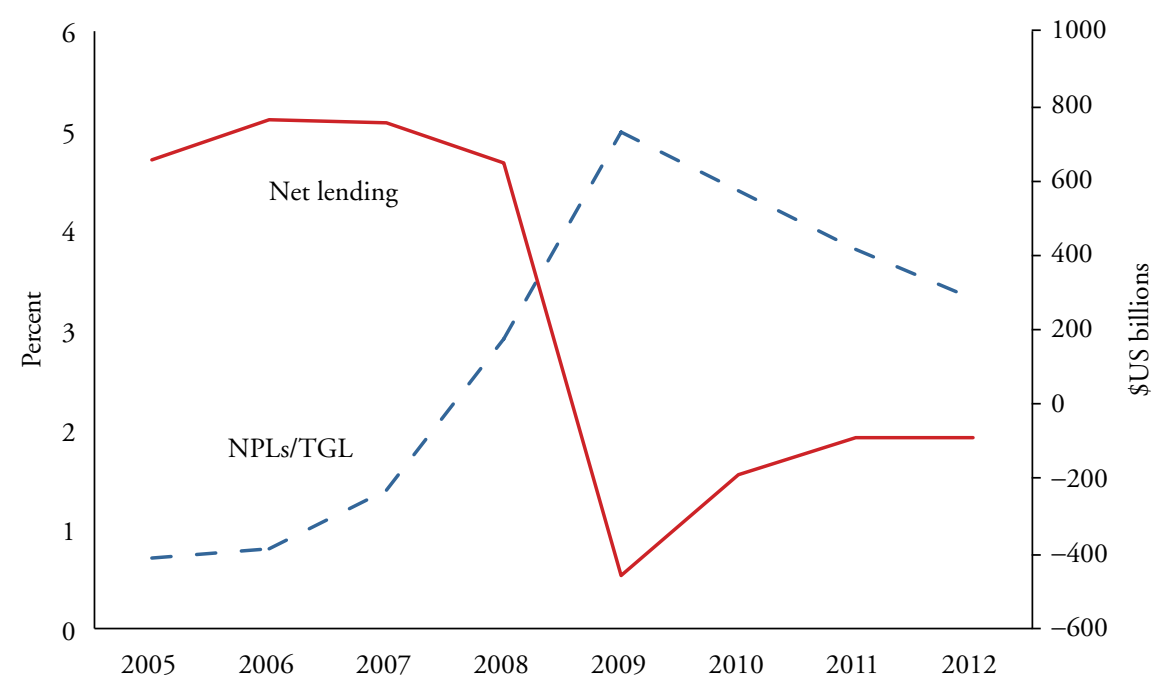

Sources: IMF, Financial Soundness Indicators, Board of Governance of the Federal Reserve System.

Figure 1 Changes in net lending (right axis) and non-performing loans (left axis) as a percentage of total loans given

net lending in the run-up to the crisis and the subsequent sharp decrease in net lending: $\$ 657$ billion in 2005 to $-\$ 458$ billion in 2009 to $-\$ 86.9$ billion dollars in 2012 . The subsequent collapse and stabilization at a lower level of net lending, post-crisis, is also obvious (Mizen 2009).

The causality of a credit crunch event is still not well understood (Kindleberger 2005; Gai/Kapadia 2010; Haldane/May 2011). Current research focuses on increases in balance sheet connectedness and complexity, viewing the banking system as a directed graph or network (May/Arinaminpathy 2010; Gleeson et al. 2011; Haldane/May 2011). There is of course a longer thread of literature on these issues. For example, Bernanke et al. (1991) study leftward shifts in the supply curve of bank loans, holding constant real interest rates and quality of bank borrowers. Kiyotaki/Moore $(1997 ; 2002)$ study the endogenous generation of temporary liquidity shocks.

The most often-repeated causal story within this literature is that a badly priced asset or asset class (for example, US subprime mortgages) causes a sharp increase in loan defaults which leads to banks provisioning for bad debts, which reduces their equity capital (Whalen 2008). The shock increases the cost of interbank funding, causing a reduction in loans into the real economy and a reduction in economic output. The feedback from drops in demand for the original asset to an inability to refinance that asset owing to credit constraints is quite clear in this story. Individual banks can fail, and fail spectacularly, when they demonstrate an inability to meet their short-run liabilities, and the impact on the real economy can be profound.

There are competing liquidity crisis stories (Minsky 1986; Koo 2009; Eggertsson/ Krugman 2012). Each of these stories revolves, in some sense, around a credit build-up within temporarily risk-loving banks enjoying lax regulatory climates, rather than individual householders making poor decisions, but the network of attendant causal linkages is similar to the first set of stories. Many new papers study flows of funds within the financial 
system empirically (Castren/Kavonius 2009; Billio et al. 2011). They find increased levels of interconnection between banks increases the probability of a credit crunch event markedly following a contraction in liquidity in one bank that propagates across the network. This is balance sheet contagion.

Our contribution is motivated by the literature, and is threefold in this paper. First, we build and solve a large two-country, five-sector stock-flow consistent macroeconomic model in the tradition of Godley/Lavoie (2007). ${ }^{1}$ Rather than focusing just on banks, or on the economy as a whole, we consider the interconnections between the financial and real sides of the economy in explicit detail.

It should be underlined that this is an open-economy model without trade but with international flows. In other words, the balance of payments only includes the capital account balance, because we wish to focus on the consequences of interbank loans in a globalized world. There are no exports (although there is a current-account balance in each country due to interest payments to and from the other country), and therefore the consequences of the credit crunches we simulate will not take into account the feedback effects on net exports. That important qualification aside, the key advantage of stock-flow consistent models is the ability to conduct an analysis of the real and financial flows and stocks at the 'world' level with a comprehensive description of the main agents such as households firms, central banks, private banks, and governments.

Second, we simulate both a one-off increase in non-performing loans and a multi-period increase in non-performing loans. Many other studies, for example Kiyatoki/Moore's (1997) classic study of credit cycles, look only at a single credit event, which, while important, tends to underestimate the long-run effects of a protracted credit crisis such as the one the world economy is currently experiencing. Our model is careful to correct for this.

Third, we contribute to the literature on imbalances within countries and within its banking institutions, in the hope of a more complete description of these important phenomena.

The rest of this paper is laid out in the standard way. Section 2 describes the main model equations. Section 3 gives the results, graphically and numerically. Section 4 concludes.

\section{MODEL}

Before describing the model's balance sheet, transaction matrices and behavioral equations, we first give some intuition for the model's supply shock transmission mechanism through the interbank loan market.

Figure 2 shows this mechanism in detail. We assume the private banking sector in this model is made up of two competing banks in each country, regulated by a national central bank. Each bank in both countries accepts deposits and provides loans to the private sector including the banking system itself (interbank loans). For the sake of simplicity, we assume that both governments do not create demand for loans. The reason for this assumption is to see the contagion of credit crunch from one bank in a specific country to the other banks in the domestic country and to foreign banks connected through interbank loans.

Running from left to right, we see that bank $A$ takes interbank loans from bank $B$ and supplies interbank loans to bank $C$. Bank $B$ takes interbank loans from bank $D$. Bank $C$ is a net debtor in this market and takes interbank loans from bank $D$, and thus Bank $D$, as drawn, is a net creditor in this market.

1. Eviews code for this model is available upon request from the authors: Stephen.kinsella@ul.ie; skhalil@pma.ps. 


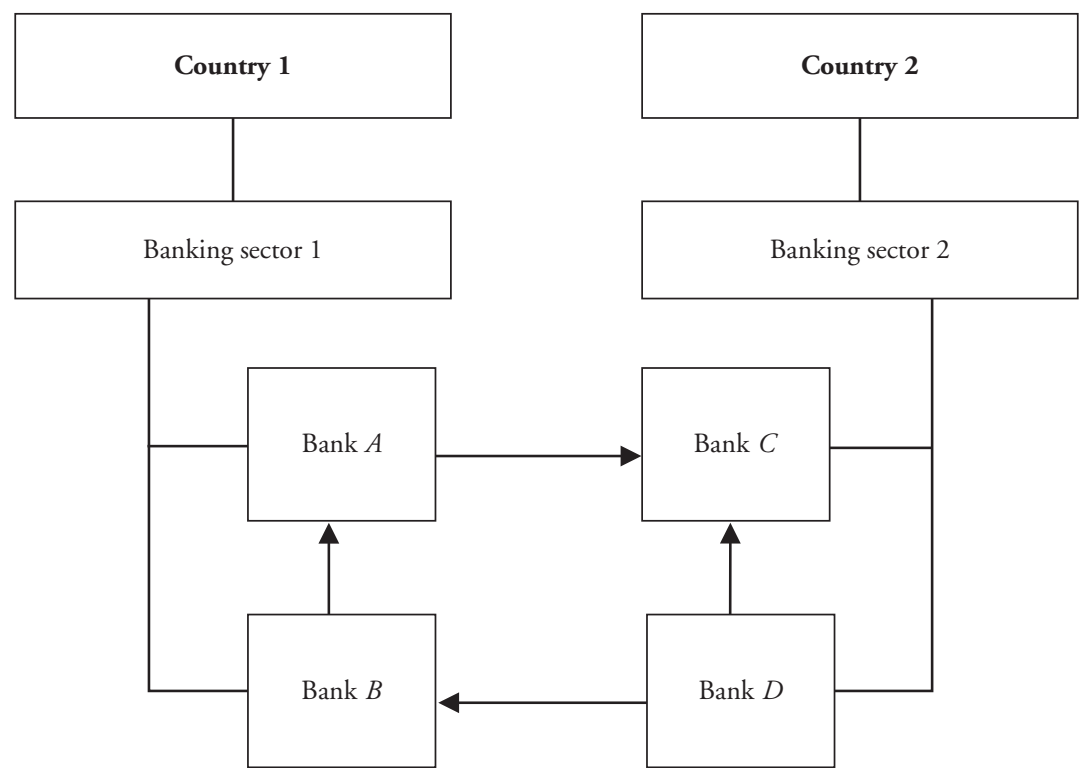

Figure 2 Transmission mechanism through the interbank market

Each bank has to pay interest on their interbank loans received, and they receive interest on their supplied interbank loans. The banks' profits are made within the differentials between incoming and outgoing interest rates. Part of the profits will go to households who hold bank shares as dividends. The remainder is held as retained earnings within each bank's capital accounts.

In each period, each bank's capital account contains the change in the bank's assets and liabilities, which gives the new flows of the bank's own funds (or bank equities), retained earnings, and the value of non-performing loans.

The model, in general, is laid out as follows. We interact two steady-state - almost identical - economies with five sectors in each economy: households, firms (the nonfinancial sector), government, central bank, and private banks. Each sector acquires assets $(+)$ and incurs liabilities $(-)$.

Again, the objective of the paper is to pull out the effects of a credit-supply shock that precipitates a decline in the supply of loans to the other sectors in the economy. To do this, we need to describe the balance sheets of our model, building a relatively elaborate trading schema within the banking sectors as we do so, and keeping the description of the rest of the economy as 'pared down' as possible. Then we introduce revaluation and transactions matrices, and write down the main behavioral equations the model uses before turning to our simulated results in Section 3.

Table 1 shows the balance sheet for our model. Large letters denote the variable under study; for example, high-powered money, $H$. High-powered money is just money issued by the central bank and is held by banks as reserves, either in the form of vault cash or as deposits at the central bank, as well as by households. Subscripts within the table show the destination sector of each entry, and whether this sector demands or supplies that quantity. So, for example, in Country 2 , households $(b)$ have a demand $(d)$ for high-powered money $\left(+H_{h}^{2} d\right)$, and in Country 1, households $(b)$ have a demand $(d)$ for high-powered money $\left(+H^{1} h d\right)$, while the second central bank supplies $\left(_{s}\right)$ this money $\left(-H^{2}{ }_{s}\right)$. 


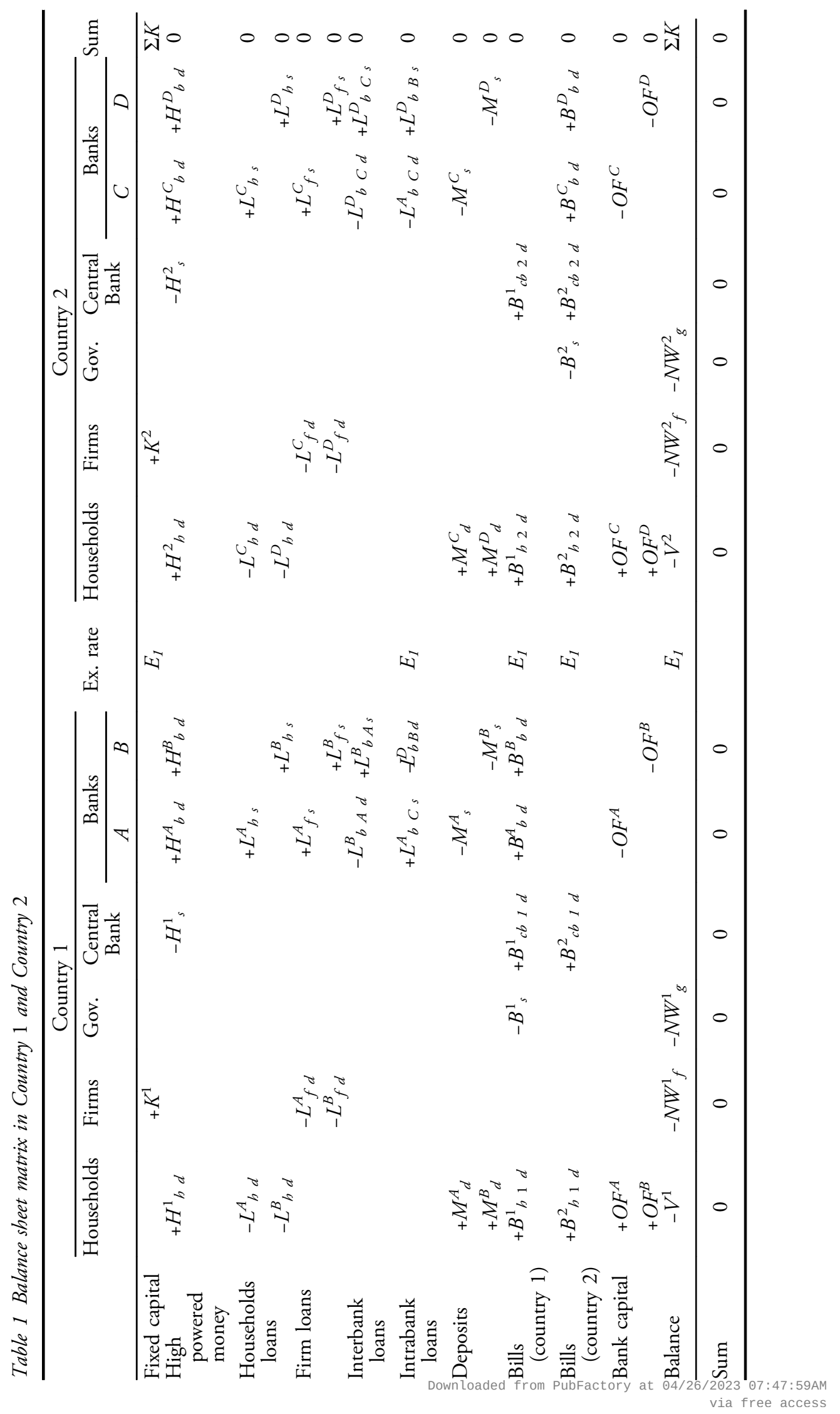


For ease of exposition we suppress subscripts and superscripts within paragraphs. Running from left to right in the table, then: in addition to holding high-powered money $(+H)$, households also hold money deposits $(+M)$ in domestic banks, local and foreign government securities $(+B)$, and bank equities $(+O F)$. Households can take loans from domestic banks $(-L)$. The total wealth of the household sector is given by $(+V)$.

Firms own tangible assets in the form of fixed capital $(+K)$. Firms take loans from domestic banks $(-L)$. The sum of their assets and liabilities gives the net worth of the firms at the end of each period $(+/-N W)$.

The government in each country is a passive actor in the system, and must mechanically finance any deficit by selling treasury bills $(B)$, both at home and abroad.

The central banks of both countries are equally stripped-down entities, only issuing money $(H)$ and holding local and foreign treasury bills.

We introduce a necessary complication in the description of private banks to study interbank contagion. Our four private banks demand and supply loans between one another nationally and internationally.

To give a sense of what is happening within the model, we reintroduce the subscript and superscript notation briefly. Bank $A$ in Country 1 creates a demand for interbank loans from bank $B$ in Country $1\left(-L^{B}{ }_{b} A d\right)$ and supplies interbank loans to bank $C$ in Country $2\left(+L_{b}^{A}{ }_{b s}\right)$. Bank B in Country 1 creates a demand for interbank loans from bank $D$ in Country $2\left(-L^{D} b_{B} \quad d\right)$ and supplies interbank loans to bank $A$ Country 1 $\left(+L^{B}{ }_{b} A s\right)$. Bank $C$ in Country 2 demands interbank loans from bank $A$ in Country 1 $\left(-L^{A}{ }_{b} C_{d}\right)$ and from bank $D$ in Country $2\left(-L^{D}{ }_{b} C d\right)$. Bank $D$ supplies loans to bank $B\left(+L^{D} b_{s}\right)$ and to bank $C\left(+L^{D}{ }_{b} \quad s\right)$.

Table 2 shows the revaluation matrix for this model. We see two revaluations of fixed capital $(k)$ and bank capital $(O F)$. Capital gains accrue to household wealth, whilst banks' own funds are treated as liabilities. The value of the firm's fixed capital is net of price inflation.

Table 3 shows the flows within the sectors and between countries of this module. A plus sign (+) means the sources of the fund, and a minus sign (-) denotes a use of those funds.

Firms have both current and capital accounts. In its current account the firm describes its activities in supplying goods and services $(+C)$ to households and the government, and providing net investment $(+I)$. The firm pays taxes $(-T)$ on its sales, it pays wages to households $(-W B)$ and pays out interest on its loans $(-r L)$ while taking account of depreciation costs $(-\delta K)$. The difference between sources and uses of funds in the firm's current account is its profits $(-F)$, transferred to households which own equity in the firm.

Households earn wages from firms $(+W B)$, they pay income taxes to the government $(-T)$ and they can, from time to time, default on their loans. Households pay interest $(r)$ on their performing loans.

Each government receives taxes $(+T)$ from firms and households and the central bank's profits $\left(+F_{c b}^{j}\right)$ and pays interest on treasury bills supplied to the other sectors locally and to the other country $(-r . B)$. The sum of these components determines the public sector borrowing requirements $(P S B R)$. As mentioned above, governments of both countries meet their public sector borrowing requirement by issuing new treasury bills $(+\Delta B)$.

Each central bank receives interest on its holdings of treasury bills from the domestic government and from the other country's government. The sum of these interest payments is the central bank's profits, and the profits of the central bank are transferred completely to the government. An accounting requirement is that any addition to the treasury bills portfolio (domestic and foreign) of the central bank must be accompanied by an 


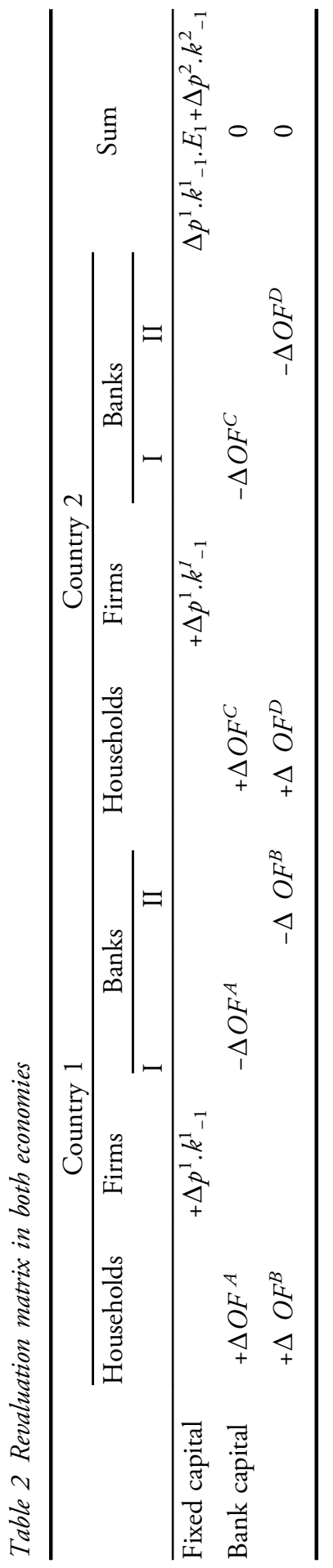




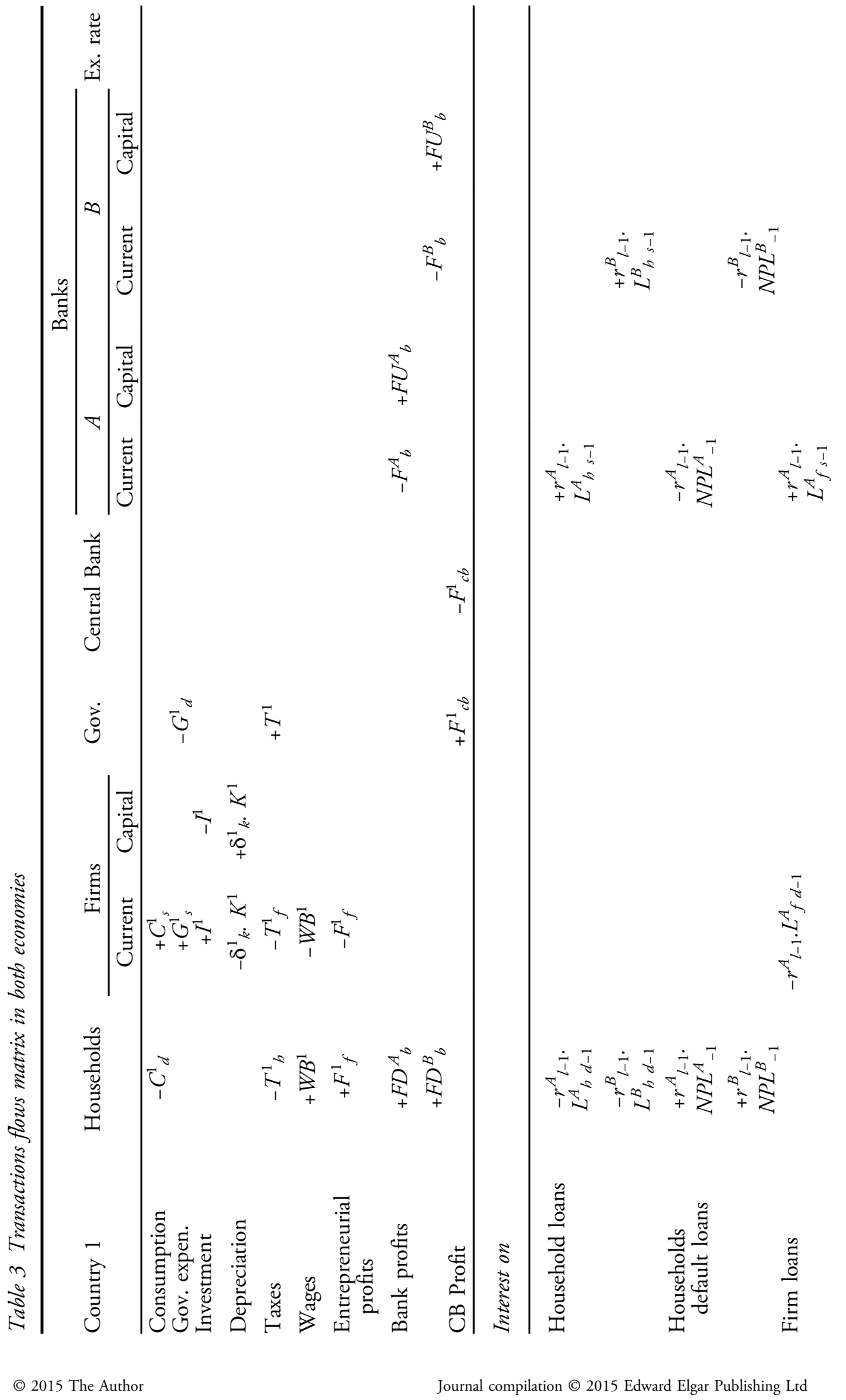




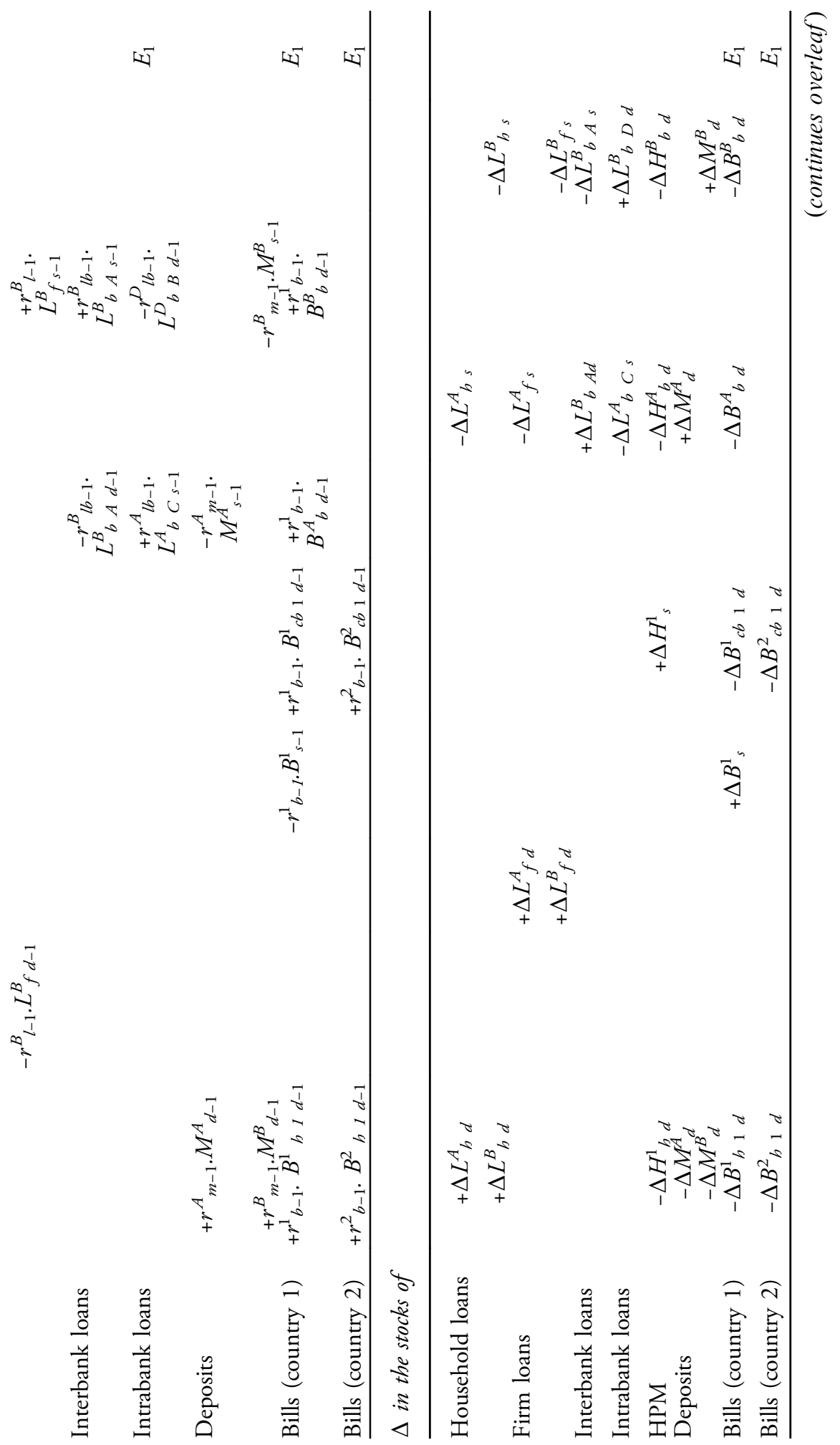




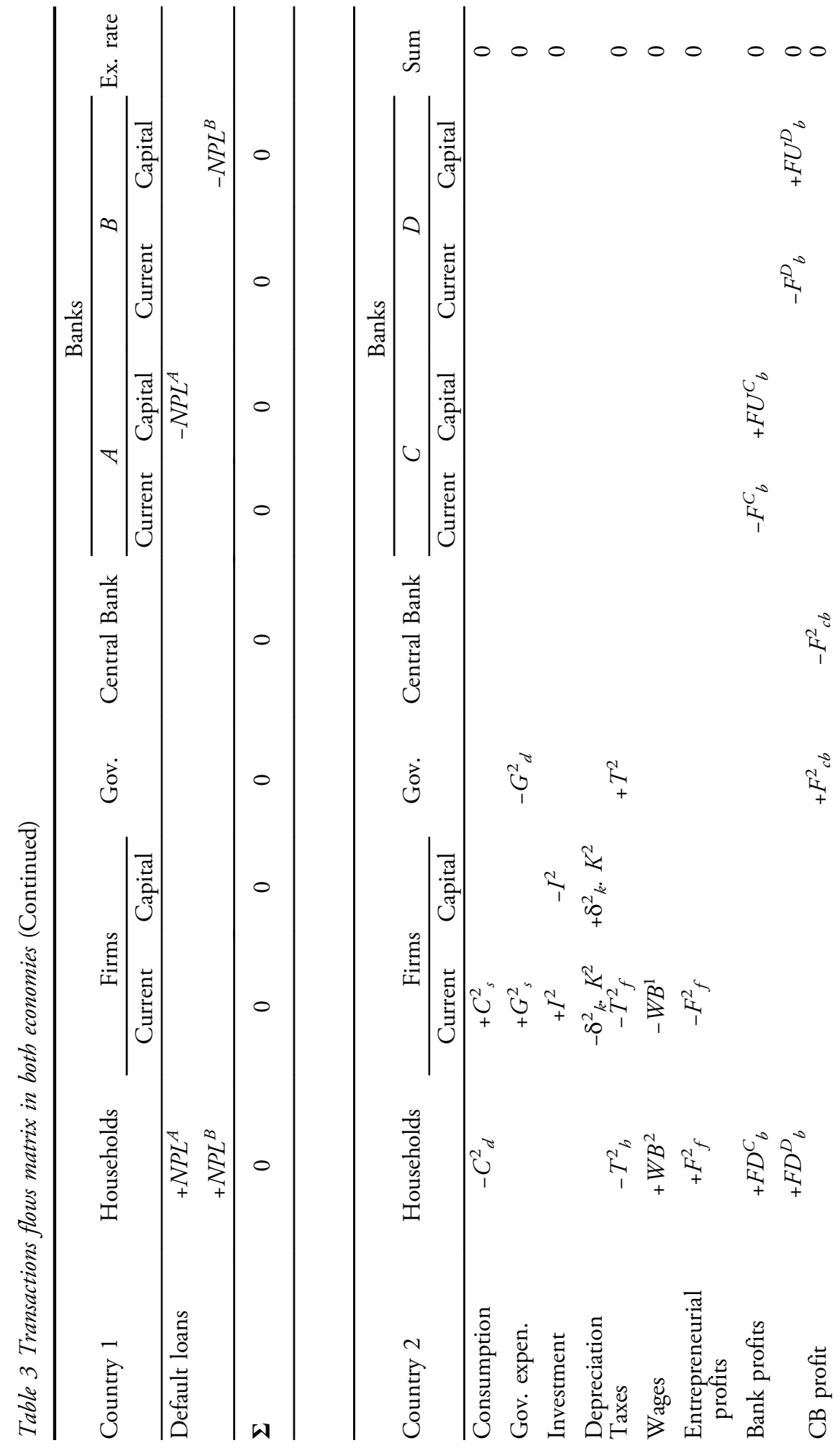




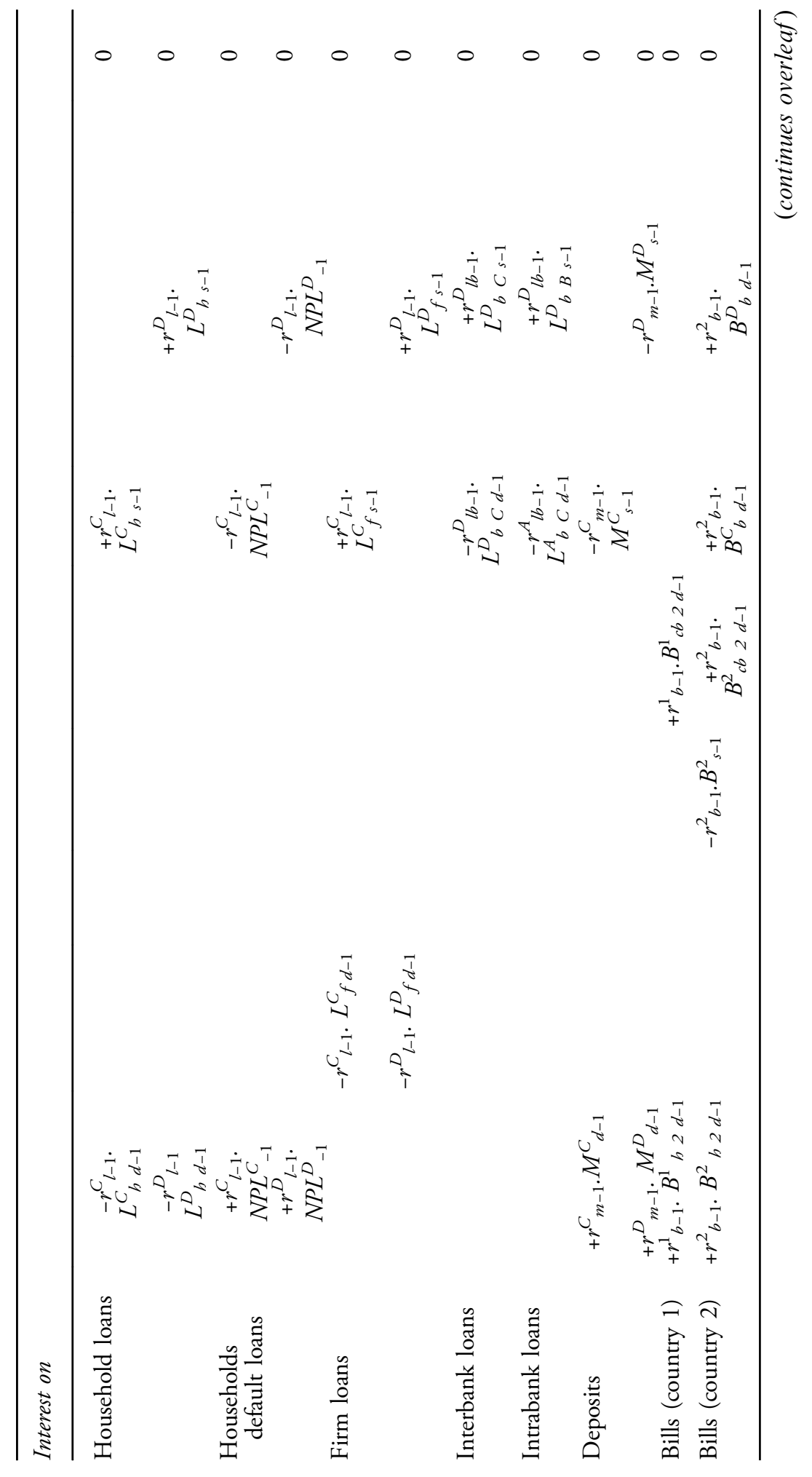




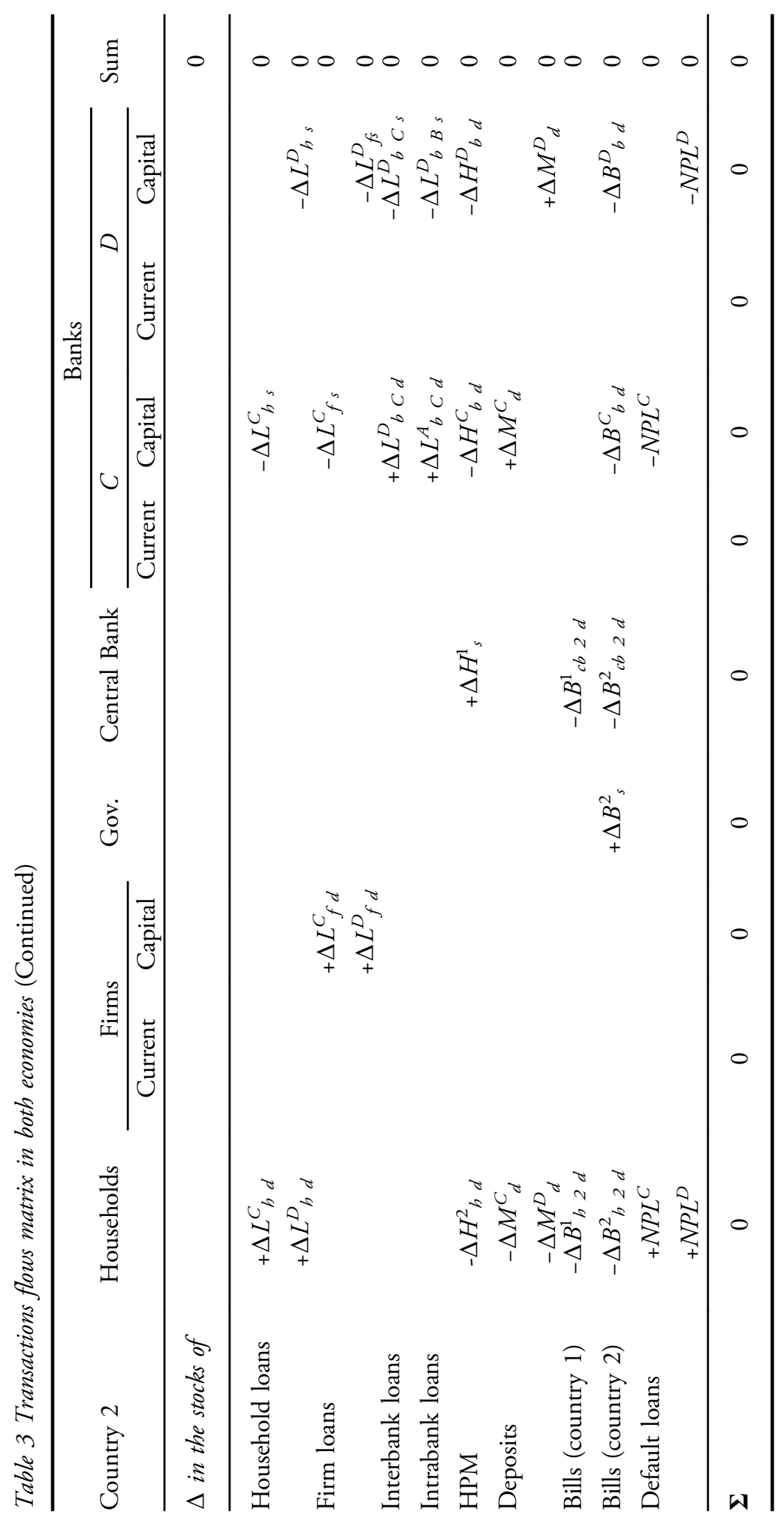


equivalent increase in the amount of high-powered money $(+\Delta H)$ to households and private banks.

Private banks, in their current account column, receive interest on their loans to households and firms, interest on their holdings of treasury bills, and pay interest to households for money deposits. We assume that some households will default on their loans, with the difference between outstanding loans $(L)$ and non-performing loans $(N P L)$ set to 5 percent initially. Thus banks receive interest just on performing loans $\left(+r_{L-1}^{i}\left(L_{h d-1}^{i}-N P L\right)\right)$.

\subsection{Model equations}

Beyond the balance, transaction, and revaluation matrices, the model proper is a set of behavioral equations governing the motion of the system.

The real output in each country is the sum of households' consumption $(c)$, government expenditure $(g)$, and investment $(i)$. This is equal to the real output of the system expressed as sales (s).

$$
y=s=c+g+i
$$

Each firm's pricing decision is a constant mark-up of the unit cost $(U C)$, which in turn is equal to the wage bill $(W B)$ paid per unit of sales $(s)$.

$$
\begin{gathered}
P=(1+\tau) \cdot U C \\
U C=\frac{W B}{s}
\end{gathered}
$$

The investment decision of each firm is given by the accounting identity of the capital account of the firm - based on the steady-state condition as mentioned above. The level of employment in each firm depends on the number of units produced $(y)$, or sold $(s)$, and on the workers' productivity of that firm $(N=s / p r)$.

Household income is given as the sum of wages, profits, and interest on financial assets held in previous periods. Disposable income is just household income minus taxes on income and interest servicing on loans and capital gains. Importantly, the household must service some part of its non-performing loans also if it is a defaulter.

We model an income distribution by breaking society in each country into three groups. The first group receives 50 percent of the disposable income of the nation. This group consumes both from their disposable income $(y d)$ and from their wealth built up in previous periods $\left(v_{-1}\right)$. Call $S h_{1}$ the first group's 'share' of the country's disposable income. Equation 4 shows the consumption function of the first group of households, with $\alpha_{1}$ and $\alpha_{2}$ denoting the marginal propensities to consume out of current and past income, respectively.

$$
c 1=\alpha_{0}+s h 1 . \alpha_{1} \cdot y d+\alpha_{2} \cdot v_{-1}
$$

The second group in society consumes all their share of disposable income plus new loans $(n l)$ obtained from banks.

$$
c 2=\operatorname{sh} 2 . y d+n l
$$

The third group is made up of those households who default on their loans and just consume their share of disposable income, so $c 3=s h 3 . y d$. The shares of the second and third groups are assumed to vary over time. In this model it is assumed that when a household defaults in its loan it moves from the second group to the third group, and thus the share 
of the third group increases when loan defaults increase and vice versa. The following are the equations of the second and third share of the total country disposable income:

$$
s h 3=\operatorname{sh} 3_{-1}+\eta \cdot \Delta\left(\frac{\sum_{i}^{x} N P L}{\sum_{i}^{x} L_{h d}}\right)
$$

where

$$
\operatorname{sh} 2=1-\operatorname{sh} 1-\operatorname{sh} 3 .
$$

Here $\eta$ is a constant that transforms the second term on the right-hand side of equation (6) into percentages. This equation states that when total non-performing loans in a country out of total loans demand increases, the share of the third group increases and at the same time the share of the second group decreases by the same percentages. Households' total consumption is just the sum of the three groups' consumption $(C=C 1+C 2+C 3)$.

Each household makes portfolio decisions based on the rate of the return on those assets. ${ }^{2}$ Cash money makes up a portion of households' consumption; households' demand for loans is equal to the supply of loans to households, and flows of bank equities are determined by the differences between banks' retained earnings and their nonperforming loans.

As mentioned above, the government of each country is assumed to use treasury bills and taxes to pay for its expenditure and transfers (interest on treasury bills, $r$, supplied for domestic and foreign markets). Where government expenditure is greater than taxation revenue $(T)$ plus the profits of the central bank $(F)$, the shortfall is made up using treasury bills, so in each period $\Delta\left(B_{s}\right)=P S B R$. The public sector borrowing requirement (PSBR) of the country is given by:

$$
P S B R=G+r_{b-1} \cdot B_{s-1}-\left(T+F_{c b}\right) .
$$

Central banks hold high-powered money, which they supply to households and banks. Central banks also hold treasury bills from both countries. The change in demand for domestic bills is dependent on flows of high-powered money and foreign treasury bills. The central banks' profits are generated by interest earned on treasury bills issued. The exchange rate is determined in the foreign bonds market:

$$
E_{1}=\frac{B_{h 2 s}^{1}}{B_{h 2 d}^{1}} .
$$

Private banks supply loans based on their liquidity and leverage ratios in any given period. Each bank also takes the change in debtor banks' liquidity into account when deciding to make a loan. For Bank $A$, for example, the loan equation is:

$$
L^{A}=L_{s-1}^{A}+\zeta_{b 1}^{A} \cdot\left(B L R^{A}-B L R^{A T}\right)+\zeta_{b 2}^{A} \cdot \Delta B L R^{C} .
$$

Where the bank liquidity ratio is given by the following equation, which is the ratio of liquid assets (government bonds or treasury bills) to liabilities (deposits):

$$
B L R^{A}=\frac{B_{b d}^{A}}{M_{s}^{A}} .
$$

2. Tobin's portfolio decision (Godley/Lavoie 2007: 458). 
Banks are able to supply more loans if their liquidity ratio is above a target ratio set by the central bank, and they provide fewer loans if their liquidity ratio is lower than the target liquidity ratio.

Banks charge interest on loans and pay interest on deposits. We shall assume that the interest rate on deposits is determined by the interest rate on government bonds and the evolution of bank liquidity ratio. As an example, for bank $A$, the interest rate on deposits is as follows:

$$
r_{m}^{A}=r_{m-1}^{A}+\xi_{m}^{A}\left(z_{1}^{A}-z_{2}^{A}\right)+\xi_{b}^{A} \cdot \Delta r_{b}^{A}
$$

where

$$
\begin{aligned}
& z_{1}^{A}=1 \text { iff } B L R^{A}<\text { bot }^{A} \\
& z_{2}^{A}=1 \text { iff } B L R^{A}>t o p^{A} .
\end{aligned}
$$

Equations (13) and (14) are to ensure that the liquidity ratio doesn't fall below a minimum value and doesn't go above a maximum value.

The lending rate to firms and households is set such that it takes into consideration the interest rate on deposits plus margin that depends on some measure of bank profits.

$$
r_{l}^{A}=r_{m}^{A}+a d d_{1}^{A}
$$

Banks acquire vault cash as a portion of money deposits. The change in banks' own funds or existing equities is equal to the retained earnings after subtracting non-performing loans. Banks' demand for treasury bills is an accounting identity determined in each period by the balance sheet of each bank. The redundant, or the hidden, equation in this model is that the central bank of Country 1 supplies vault cash to bank $D$ on demand.

\section{RESULTS}

After setting up our model's equations and identities, to start simulations we need to assign values for all model parameters and stocks. Choosing these values depends, in part, on some plausible stock-to-flow ratios and parameters (Godley/Cripps 1983).

These values must ensure the model converges, retains its consistency, and is broadly in line with the status quo.

We simulate two different types of shock to the steady state of the system. First, we look at a temporary increase in non-performing loans and the attendant effects on the real economy. Second, we look at a longer run of increasing non-performing loans and the effects it has on the real economy.

\subsection{Scenario 1: a temporary increase in non-performing loans}

The first scenario assumes a one-time increase in country 1 households' non-performing loans taken from bank $A$. In the baseline scenario it is assumed that the ratio of households' default loans forms 5 percent of the total loans stock. In the first scenario this ratio is assumed to increase in period 15 to reach 10 percent of total households' loans from bank $A$.

The charts in Figure 3 tell the story quite well. An increase in non-performing loans leads to an immediate decline in bank $A$ 's income receipts, which, predictably, affects bank $A$ 's own funds negatively. Bank $A$ 's demand for treasury bills also suffers, and its 

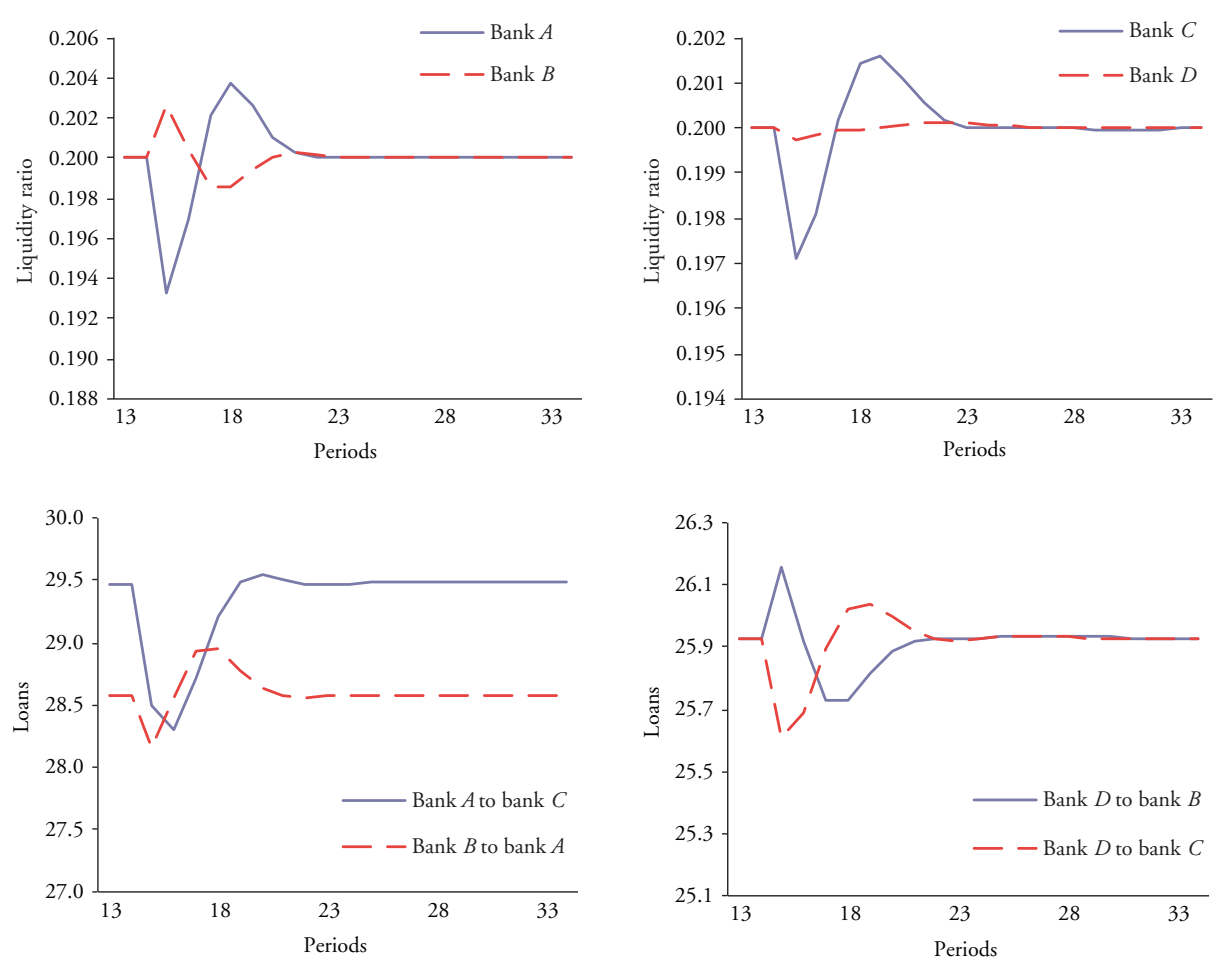

Figure 3 Simulation of a one-time increase in non-performing loans in Bank A in Country 1. Top left: evolution of bank liquidity ratios in Country 1. Top right: evolution of bank liquidity ratios in Country 2. Bottom left: evolution of interbank loans supply in Country 1. Bottom right: evolution of interbank loans supply in Country 2

liquidity declines, reducing its capability to supply loans to households, firms, and of course to the interbank market. The upper panels in Figure 3 show the evolution of the liquidity ratios of banks $A, B, C$, and $D$ after the increase in non-performing loans in bank $A$.

We can trace the contagion effects quite clearly. In the interbank loans market, the decline in bank $A$ 's liquidity ratio forces the bank to reduce the supply of interbank loans to bank $C$. Bank $B$ then becomes afraid about bank $A$ 's solvency, which may affect bank $A$ 's capability to fulfill its short- and long-term liabilities. Thus bank $B$ may be affected. As a consequence, bank $B$ decreases its interbank loans supply to bank $A$. To be clear: bank $B$ 's expectations cause the feedback from non-performing loans in Bank $A$ to a further reduction in available credit lines.

We can see the interbank loans supplied in Country 1 after the increase in bank $A$ 's non-performing loans. The solid line shows the evolution of interbank loans supply of bank $D$ to bank $B$. The dash line shows the evolution of interbank loans supply of bank $D$ to bank $C$. As shown in the figure, the supply of loans of bank $D$ to bank $C$ declines due to the decline in bank $C$ 's liquidity. Bank $C$ 's liquidity ratio declines due to the decline in the received interbank loans from bank $A$. As a consequence bank $D$ decreases its interbank loans to bank $C$. After that, bank $B$ decreases interbank loans to 
bank $A$, its liquidity ratio increases, and, owing to that, interbank loans supplied to bank $B$ by bank $D$ increase.

As mentioned above, banks in this model aim to keep their liquidity at a target level set by the central bank. When a bank's liquidity ratio falls below the target, banks decrease loans, causing a credit crunch in the real economy. When a bank's liquidity rises above the target, banks lend more in a credit expansion. In this scenario, decreasing loans supply will lead to an increase in bank liquidity and reach levels above the target. With the increase in bank liquidity, banks start to lend more. After a certain period of time, bank liquidity starts to decline again and thus lending falls, pulling out a rather 'Minskyian' story from this simulation.

This process will continue until banks find their liquidity ratio equal to the target liquidity ratio. A credit crunch will affect the domestic economy as well as the foreign economy through the interbank markets in both countries.

\subsubsection{The effects of a credit crunch on the real economy}

Figure 4 shows the evolution of real output in both countries. We can see that real output declines in both countries immediately after the increase in non-performing loans of bank $A$ by households.

There are two channels through which a credit crunch affects the real economy in both countries in this model. The first is through firms' investments and the second is through households' consumption. The decline in bank $A$ 's liquidity leads to a decline in its lending to households and firms. The increase in bank $B$ 's liquidity leads to an increase in its lending to firms and households.

We can also see the evolution of loans supplied by banks $A$ and $B$ to firms and households in the first country. Clearly, once the supply of loans contracts, the real economy becomes vulnerable. The middle panels of Figure 4 show the evolution of loans supplied by banks $C$ and $D$ to firms and households in Country 2. The rate of increase or decrease in loans supplied clearly follows the liquidity reduction in both countries.

When loan supply to firms declines, investments decline and thus output declines. The other channel that affects real output is household consumption. There are two effects on household consumption; one is direct, the other is indirect. In this model, income group 2 households are assumed to ask for loans to cover part of their consumption. When loans to households decline, the consumption levels of these households will decline too, and real output falls.

The indirect effect comes from changes in household disposable income. When loans supplied to firms decline, investment declines and also consumption - a further feedback through the direct effects on consumption. This leads to a decline in firms' sales, which leads to a decline in wages and profits and disposable income. Disposable income declines due to the decline in capital gains - banks' own funds - and increases due to the increase in non-performing loans, but these two elements tend to cancel each other out.

These declines in investment, consumption, and output in both countries continue for several periods, then they start to increase again and reach higher levels than the steady-state levels following changes in banks' behavior in lending. Subsequently, then, each series starts to decline again towards the steady-state levels achieved before the imposition of the shock.

Interest rates in the interbank markets and on loans to firms and to households evolve depending on target bank profits, interest on assets, and stocks of loans supplied. When the rate of non-performing loans increases, banks' own funds tend to decline, so bank liquidity declines, and thus stocks of loans supplied, which leads perforce to a decline in bank profits. 

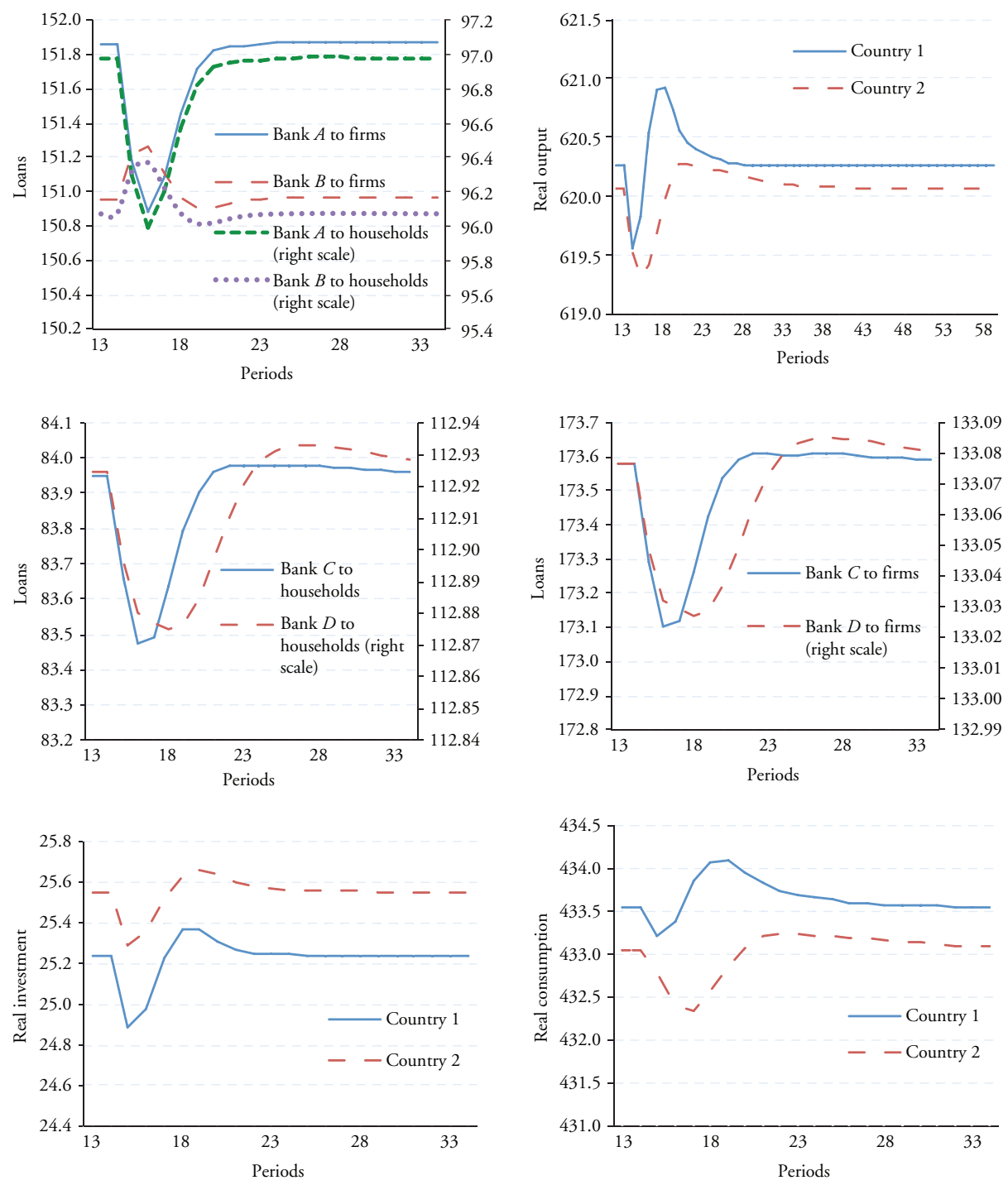

Figure 4 Top left: loans by Banks A and B to firms and households. Top right: evolution of real output in both countries. Middle left: lending by banks $\mathrm{C}$ and $\mathrm{D}$ to households. Middle right: lending by banks $\mathrm{C}$ and $\mathrm{D}$ to firms. Bottom left: changes in real investment in both countries. Bottom right: changes in real consumption in both countries

For banks to keep their profits close to their targets, they find themselves needing to increase the interest rates on loans supplied in each period. Figure 5 shows the evolution of interest rates on loans to households and to firms in both countries after a one-time increase in bank $A$ 's NPL.

As shown in Figure 5, bank $A$ increases its interest rates on loans much more compared with the other banks, owing to the losses that come from the increase in NPL, besides the 

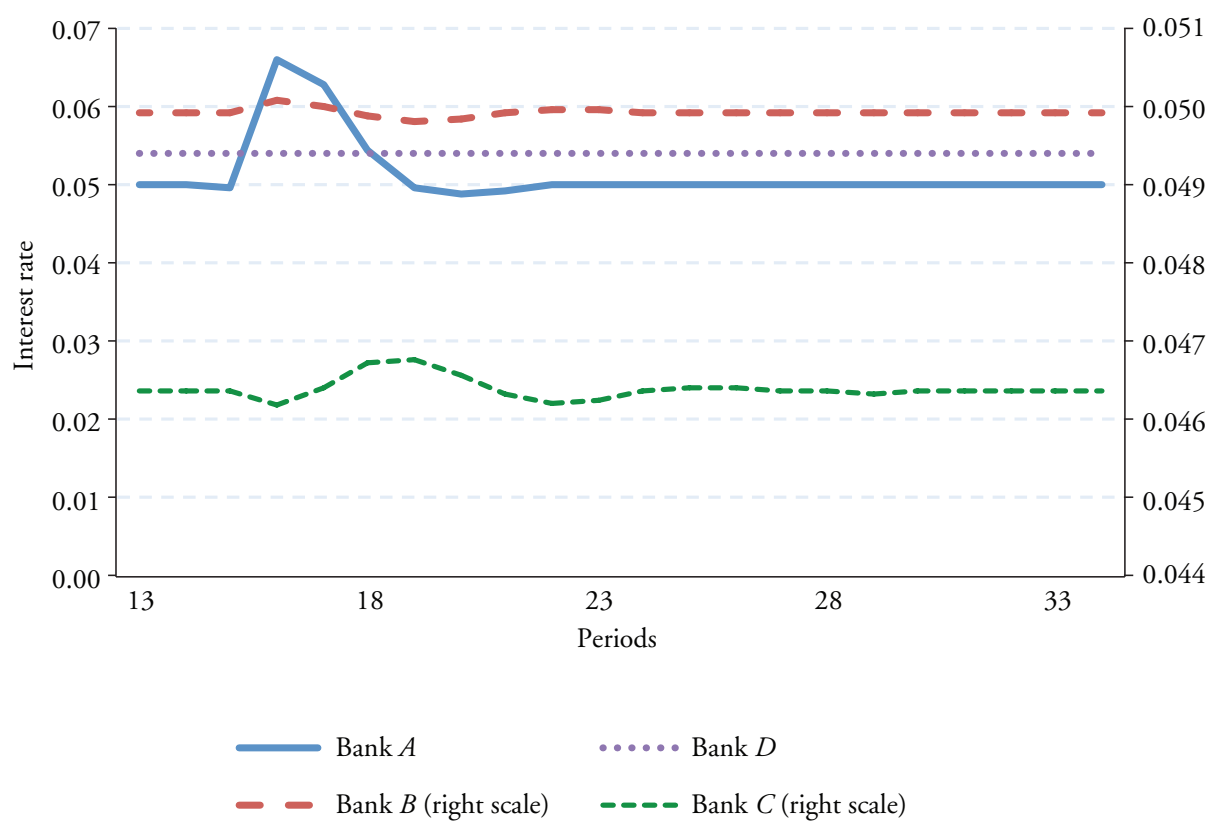

Figure 5 Evolution of loans interest rates in both countries

change in the stock of loans supplied. The other bank response is mainly due to the change in the stock of loans supplied to the interbank markets and to households and firms. Interest rates on interbank loans follow the same pattern of the interest rates on loans to households and firms.

\subsection{The effects of a multi-period increase in non-performing loans}

The second scenario assumes an increase in households' non-performing loans from bank $A$ for five periods starting from period 15. The reason behind this scenario is to see the effect of a several-time increase in non-performing loans on the economy, which may allow us to generalize our results. As before, the ratio of non-performing loans as a share of total households' demand for loans will increase from 5.0 percent to 10.0 percent.

Figure 6 shows the evolution of interbank loans supply in both countries after the increase in non-performing loans of bank $A$ (second scenario) compared with an increase in non-performing loans for one time only (the first scenario).

In this figure, it should be noted that the interbank loan supply is summed for both banks in the country, and not for a specific bank as in Figures 4 and 5 above. Figure 6 shows that the effect of a more than one-time increase in non-performing loans is pronounced. The credit supply shock has a more negative effect on interbank loans supplied in the second scenario compared with the first scenario in both countries. Thus interbank lending takes more time to return to its previous levels before the shock in the second scenario compared with the first scenario.

Figure 7 shows the effect of an increase in the non-performing loans of bank $A$ on loans supplied to firms and households in both countries in both scenarios. This increase in non-performing loans in the second scenario has a more negative effect on loans 


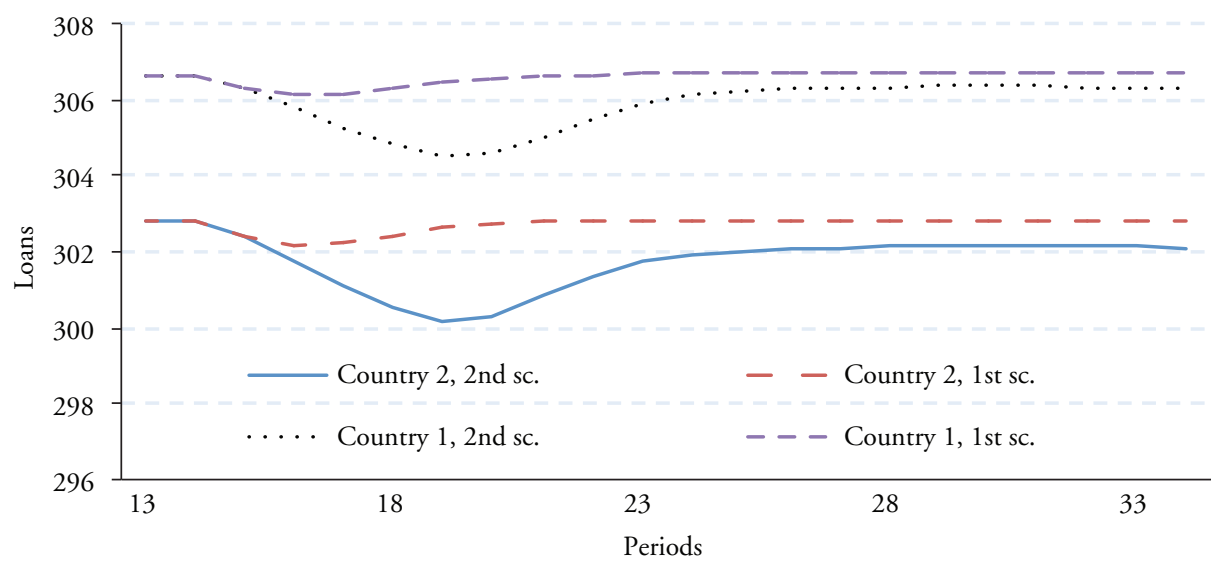

Figure 6 Evolution of interbank loans supplied in both countries in Scenario 1 (single-period increase in bad loans) and Scenario 2 (multi-period increase in bad loans)
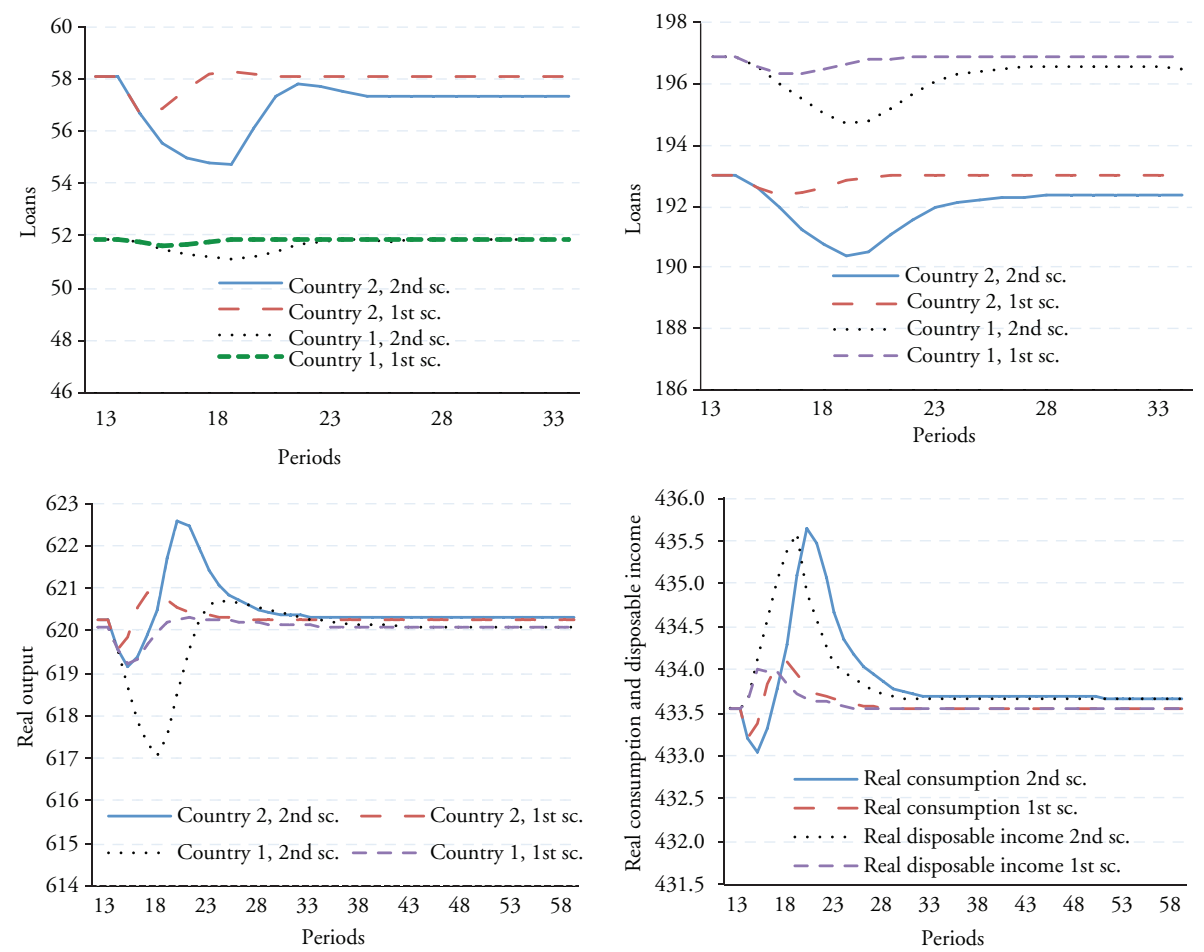

Figure 7 Top left: effect of an increase in the non-performing loans of bank A on loans supplied to firms in both single and multi-period scenarios. Top right: effect of an increase in the non-performing loans of bank A on loans supplied to households in both single-and multi-period scenarios. Bottom left: effect of credit crunch on real output in both single-and multi-period scenarios. Bottom right: effect of credit crunch on real consumption and disposable income in both scenarios 


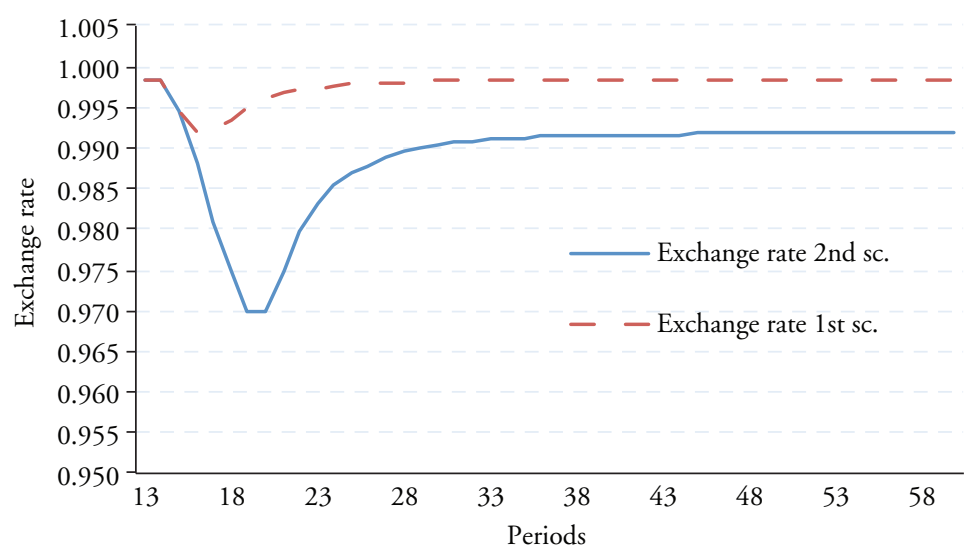

Figure 8 Evolution of the exchange rate in both scenarios

supply compared with the first scenario in both countries as the case in the interbank lending market.

When non-performing loans increase in bank $A$ for more than one period, bank $A$ starts facing losses on its own funds. This loss naturally affects bank A's liquidity, which ends up below the target level set by the central bank. This forces bank $A$ to decrease loans supplied in the interbank market to households, and to firms to try to regain its liquidity target. The deleveraging attempt causes a marked contraction in real economic output, investment, and consumption, as credit dries up. The continuation of the higher levels of non-performing loans forces bank $A$ to continue decreasing loans supplied, period after period. As discussed in the first scenario, bank $A$ 's credit crunch will spread to the other domestic and foreign banks via the same propagation mechanism.

Figure 7 also shows the real output in both countries in both scenarios. The credit crunch in both countries has bigger effects on real output in the second multi-period scenario compared with the first scenario. The evolution of real output follows the evolution of banking behavior in lending both in the interbank lending market and in the domestic market.

We can also show the evolution of real households' consumption and real disposable income in the first country in the case of the second scenario compared with the first scenario. As shown in Figure 7, real consumption and real disposable income are affected in the second scenario more than in the first scenario. A credit crunch in the first country spreads to the other country, which will have a negative effect on households' real consumption and on real disposable income.

The exchange rate, which mediates between the two economies in the standard fashion, is also adversely affected in the multi-period scenario, as we can see from Figure 8.

\section{CONCLUSION}

The aim of this paper is to use simulation to study the effect of a single- and multi-period increase in non-performing loans in a two-country setting.

The interactions between banks are explicitly modeled, as are the effects on the real economy. We see the evolution of a series of bad loans on liquidity within banks, between banks, and between the financial and real sectors of the economy. 
The model is complex enough to track the flows of liquidity between individual banks, which is the main contribution of the paper.

We find that a single-period increase in non-performing loans in one bank can be compensated for quite easily by the network of connections represented in this model by the interbank market. When the increase in non-performing loans is long-lived, however, interconnection becomes a curse as contagion spreads to undamaged banks. This feeds back into the real economy of both our simulated economies, as a decreased supply of loans, which reduces the real output of each economy in different ways.

In our model we assumed that banks react correctly to the decline in liquidity by squeezing loans supply to keep their liquidity at its target level imposed by the central bank, which led banks to return to the levels before the shock. This highlights the important role of central banks in regulating and monitoring banks, and provides a direction for future research: what happens when banks do not react correctly? We will also concentrate on simulating policy responses to the problem of persistent bad debt in bad banks choking good banks.

\section{REFERENCES}

Anand, K., Gai, P., Kapadia, P., Brennan, S., Willison, M. (2013): A network model of financial system resilience, in: Journal of Economic Behavior \& Organization, 85, 219-235.

Bernanke, B., Lown, S., Friedman, M. (1991): The credit crunch, in: Brookings Papers on Economic Activity, The Brookings Institution, 2, 205-247.

Billio, M., Getmansky, M., Lo, A., Pelizzon, L. (2011): Econometric measures of systemic risk in the finance and insurance sectors, MIT Sloan Research Paper No 4774-10; NBER Working Paper No 16223.

Castren, O., Kavonius, K. (2009): Balance sheet interlinkages and macro-financial risk analysis in the Euro area, European Central Bank Working Paper No 1124.

Eggertsson, G., Krugman, P. (2012): Debt, deleveraging, and the liquidity trap: a Fisher-MinskyKoo approach, in: The Quarterly Journal of Economics, 127(3), 1469-1513.

Gai, P., Kapadia, S. (2010): Contagion in financial networks, Bank of England Working Paper No 383.

Gleeson, J., Hurd, T., Melnik, S., Hackett, A. (2011): Systemic risk in banking networks without Monte Carlo simulation, Mimeo.

Godley, W., Cripps, T. (1983): Macroeconomics, Oxford: Oxford University Press.

Godley, W., Lavoie, M. (2007): Monetary Economics: An Integrated Approach to Credit, Money, Income, Production and Wealth, London: Palgrave Macmillan.

Haldane, A., May, R. (2011): Systemic risk in banking ecosystems, in: Nature, 469, 351-355.

Kindleberger, C. (2005): Manias, Panics, and Crashes: A History of Financial Crises, 5th edn, New York: Palgrave Macmillan.

Kinsella, S. (2012): Is Ireland really the role model for austerity?, in: Cambridge Journal of Economics, 36(1), 223-235.

Kinsella, S., Lyons, R. (2011): A return to managing the Irish economy, in: Burke, E., Lyons, R. (eds), Next Generation Ireland, Dublin: Blackhall Press, 65-90.

Kiyotaki, N., Moore, J. (1997): Credit cycles, in: Journal of Political Economy, 105(2), 211-248.

Kiyotaki, N., Moore, J. (2002): Balance sheet contagion, in: American Economic Review, 92(2), 46-50.

Koo, R. (2009): The Holy Grail of Macroeconomics: Lessons from Japan's Great Recession, London: Wiley.

May, R., Arinaminpathy, N. (2010): Systemic risk: the dynamics of model banking systems, in: Journal of the Royal Society Interface, 46, 823-838.

Minsky, H. (1986): Stabilizing an Unstable Economy, New York: McGraw-Hill.

Mizen, P. (2009): The credit crunch of 2007-2008: a discussion of the background, market reactions, and policy responses, in: Federal Reserve Bank of St. Louis Review, 90, 531-567.

Whalen, C. (2008): Understanding the credit crunch as a Minsky moment, in: Challenge, 51(2), 91-109. 